\title{
Aerosol indirect effects on continental low-level clouds over Sweden and Finland
}

\author{
M. K. Sporre ${ }^{1}$, E. Swietlicki ${ }^{1}$, P. Glantz ${ }^{2}$, and M. Kulmala ${ }^{3}$ \\ ${ }^{1}$ Department of Physics, Lund University, Box 118, 22211 Lund, Sweden \\ ${ }^{2}$ Department of Applied Environmental Science, Stockholm University, 11418 Stockholm, Sweden \\ ${ }^{3}$ Department of Physics, University of Helsinki, P. O. Box 64, 00014 Helsinki, Finland \\ Correspondence to: M. K. Sporre (moa.sporre@nuclear.lu.se)
}

Received: 7 April 2014 - Published in Atmos. Chem. Phys. Discuss.: 21 May 2014

Revised: 16 October 2014 - Accepted: 17 October 2014 - Published: 19 November 2014

\begin{abstract}
Aerosol effects on low-level clouds over the Nordic Countries are investigated by combining in situ ground-based aerosol measurements with remote sensing data of clouds and precipitation. Ten years of number size distribution data from two aerosol measurement stations (Vavihill, Sweden and Hyytiälä, Finland) provide aerosol number concentrations in the atmospheric boundary layer. This is combined with cloud satellite data from the Moderate Resolution Imaging Spectroradiometer and weather radar data from the Baltic Sea Experiment. Also, how the meteorological conditions affect the clouds is investigated using reanalysis data from the European Centre for Medium-Range Weather Forecasts.

The cloud droplet effective radius is found to decrease when the aerosol number concentration increases, while the cloud optical thickness does not vary with boundary layer aerosol number concentrations. Furthermore, the aerosolcloud interaction parameter (ACI), a measure of how the effective radius is influenced by the number concentration of cloud active particles, is found to be somewhere between 0.10 and 0.18 and the magnitude of the ACI is greatest when the number concentration of particles with a diameter larger than $130 \mathrm{~nm}$ is used. Lower precipitation intensity in the weather radar images is associated with higher aerosol number concentrations. In addition, at Hyytiälä the particle number concentrations is generally higher for non-precipitating cases than for precipitating cases. The apparent absence of the first indirect effect of aerosols on low-level clouds over land raises questions regarding the magnitude of the indirect aerosol radiative forcing.
\end{abstract}

\section{Introduction}

Aerosol particles are required for clouds to form under atmospheric conditions. The aerosol loading in the atmosphere has significantly increased since the beginning of the industrial revolution, which may have altered the microphysical properties of clouds (Boucher et al., 2013). For the same amount of liquid water, polluted clouds with more and smaller droplets reflect more sunlight than non-polluted clouds with few large droplets (Twomey, 1974). Smaller cloud droplets have also been hypothesized to lead to a reduction in drizzle from the clouds, which could lead to a prolonged cloud lifetime (Albrecht, 1989). These anthropogenic impacts that the aerosols have on clouds are named the first and second indirect aerosol effects.

The estimates of the indirect aerosol effects are associated with large uncertainties (Lohmann et al., 2010). One reason for this is that different types of clouds are more or less sensitive to changes in aerosol number concentrations and that the prevailing cloud types vary across the globe. The fact that different types of clouds have diverse effects on climate also introduces uncertainties. Low-level stratiform clouds mainly reflect incoming short-wave solar radiation but do not affect the outgoing long-wave radiation to any great degree (Boucher et al., 2013). These clouds are very common over subtropical oceans but are also present over land and other parts of the ocean.

The first indirect aerosol effect in stratiform clouds has been investigated using a range of techniques such as in situ measurements with aircraft, remote sensing from the ground and space, model simulations and combinations of these. Many previous studies have found that an increased 
aerosol index or aerosol number concentration are associated with smaller cloud droplet sizes (Costantino and Breon, 2013; Twohy et al., 2005; Menon et al., 2008). The results regarding the hypothesized increase in cloud albedo or cloud optical thickness (COT) due to smaller and more numerous droplets, are however not as consistent. Some studies (Sporre et al., 2012; Chameides et al., 2002; Guo et al., 2007) have indeed found that the COT increases in polluted air masses while other studies find no correlation between COT and higher particle concentrations (Twohy et al., 2005; Costantino and Breon, 2013). The reasons for the diverging results are thought to be enhanced entrainment of dry air into the clouds due increased cloud droplet number concentrations (Ackerman et al., 2004; Wood, 2007; Bretherton et al., 2007) or/and that air masses with higher aerosol loading often are associated with drier meteorological conditions (Brenguier et al., 2003). Both these effects lead to cloud thinning due to reduced LWP (liquid water path) and/or the vertical extent of the clouds.

The second indirect aerosol effect (cloud lifetime effect) has also been investigated by various methods with varying results. Several studies using different methods have found that precipitation or precipitation rates decrease in low-level clouds formed in environments with high aerosol number concentrations (Ferek et al., 2000; Lu et al., 2009; Cheng et al., 2007). Whether a suppression of precipitation causes an increased cloud lifetime has however been very complicated to determine (Stevens and Feingold, 2009).

Sporre et al. (2014) combined ground-based measurements of aerosol number concentrations with satellite cloud retrievals and weather radar precipitation data to investigate convective clouds over Sweden and Finland. This study uses the same data sets although the focus here is on low-level clouds. Ten years of aerosol number concentration measurements from the two ground-based aerosol monitoring stations Vavihill (Sweden) and Hyytiälä (Finland) have been combined with satellite data from the MODIS instrument onboard the Terra and Aqua satellites to find out whether or not aerosol number concentrations affect cloud properties such as cloud effective radius $\left(r_{\mathrm{e}}\right)$ and COT. Weather radar data from the BALTEX project are used as well to determine if the aerosol number concentrations affect drizzle formation. Furthermore, how the meteorological conditions affect the low-level clouds and the indirect aerosol effects are investigated by utilizing reanalysis data from the ECMWF (European Centre for Medium-Range Weather Forecasts). Table 1 summarizes the data sets and indicates where they can be accessed (all data sets are free to use for research purposes). Marine low-level clouds have been the subject of many previous investigations but this study instead focuses on continental low-level clouds that are more frequently influenced by anthropogenic aerosols.

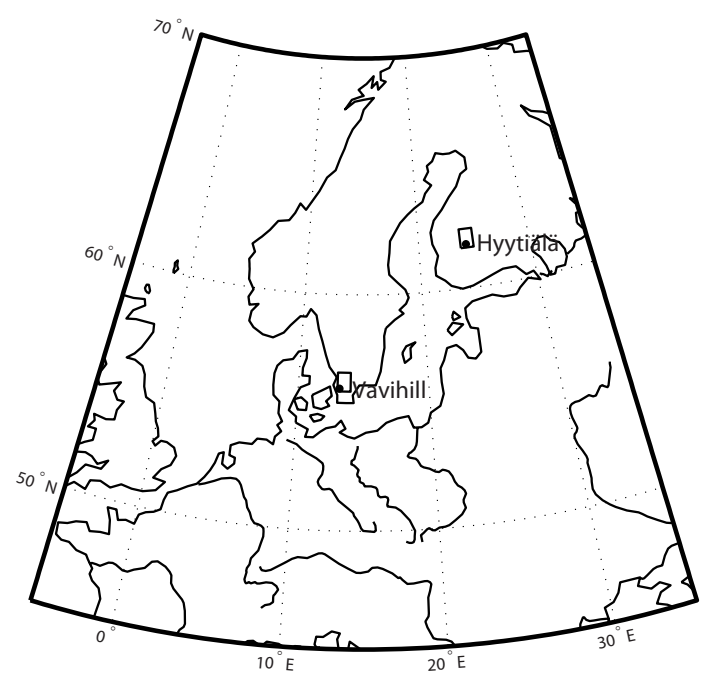

Figure 1. Map showing the locations of the ground-based in situ measurement stations and the surrounding areas used for the satellite retrieved cloud products.

\section{Method}

\subsection{Aerosol measurement stations}

Data from ground-based aerosol measurement stations at Vavihill and Hyytiälä (Fig. 1) for the periods 2001-2009 and 2000-2009 respectively, have been used in this investigation. Both stations are part of ACTRIS (Aerosols, Clouds, and Trace gases Research InfraStructure Network) network. The stations have similar seasonally averaged aerosol number size distributions but Vavihill is more influenced by continental aerosols than Hyytiälä. Hyytiälä on the other hand experiences a greater seasonal variation in number concentrations than Vavihill (Asmi et al., 2011).

The Vavihill station (Kristensson et al., 2008) is located in southern Sweden $\left(56^{\circ} 01^{\prime} \mathrm{N}, 13^{\circ} 09^{\prime} \mathrm{E}, 172 \mathrm{~m}\right.$ a.s.l.). Aerosol number size distributions between 3 and $900 \mathrm{~nm}$ have been measured by a Differential Mobility Particle Sizer (DMPS) since 2001. In this study, data from a cloud condensation nuclei (CCN) counter (Fors et al., 2011) that was placed at the station in 2008 and 2009 has also been used. Vavihill is a background station without any large pollution sources nearby.

The other station SMEARII $\left(61^{\circ} 51^{\prime} \mathrm{N}, \quad 24^{\circ} 17^{\prime} \mathrm{E}\right.$, 181 ma.s.1.) in Hyytiälä in southern Finland (Hari and Kulmala, 2005) is also a background station. Number size distribution measurements have been ongoing since 1996 (Aalto et al., 2001), starting at a size range 3-500 nm which was extended up to $1000 \mathrm{~nm}$ in December 2004. Only data from February 2000 and onwards were used here, since for this period the in situ measurements coincide with the satellite observations. Data from a CCN counter that was operated in Hyytiälä during parts of the years 2008 and 2009 
Table 1. Summary of the data sets used in this study.

\begin{tabular}{lll}
\hline Site and data source & Main parameters & Database \\
\hline Vavihill & $\begin{array}{l}\text { Aerosol number size distributions, } \\
\text { cloud condensation nuclei } \\
\text { Aerosol number size distributions, } \\
\text { Hyytiälä }\end{array}$ & EBAS \\
MODIS & $\begin{array}{l}\text { Effective radius, cloud } \\
\text { optical thickness }\end{array}$ & $\begin{array}{l}\text { MODIS/ladsweb } \\
\text { http://ladsweb.nascom.nasa.gov/index. } \\
\text { html } \\
\text { http://www.ecmwf.int/products/data/ } \\
\text { requires login }\end{array}$ \\
& $\begin{array}{l}\text { Potential temperature, } \\
\text { relative humidity, } \\
\text { specific humidity } \\
\text { Radar reflectivity composites }\end{array}$ & $\begin{array}{l}\text { http://produkter.smhi.se/brdc/ } \\
\text { requires login }\end{array}$ \\
\hline
\end{tabular}

(Sihto et al., 2011) have also been analysed. Since the CCN counter data are not available during the entire investigation period, the aerosol number concentration of particles with sizes greater than $130 \mathrm{~nm}\left(\mathrm{~N}_{130}\right)$ will be used as a proxy for the CCN.

The particle number concentrations measured at both stations were averaged over $5 \mathrm{~h}(2.5 \mathrm{~h}$ before and after the satellite overpass) to obtain values representative for the entire area captured by the satellite sensor. Using longer (up to $24 \mathrm{~h}$ ) or shorter (down to $1 \mathrm{~h}$ ) time intervals did not alter the results considerably. Days with a high variation in aerosol particle number concentrations during these $5 \mathrm{~h}$ were removed from the study to ensure that the clouds investigated were formed under similar conditions.

\subsection{Satellite data}

The satellite data used in this investigation were obtained by the MODIS sensors onboard the polar orbiting Terra and Aqua satellites. The instruments provide satellite scenes over Sweden and Finland sometime between morning and early afternoon, local time. The scenes were manually screened for low-level clouds over the aerosol stations by studying true colour visible, COT and cloud top temperature satellite scenes, and one image per day was selected. The true colour visible and the COT images were first investigated to ensure that the cloud cover was extensive and that the clouds were not convective, while top temperature was investigated to ensure that the clouds were low-level clouds. Images when the stations were situated as close to the middle of the satellite scene as possible were chosen to minimize the distortion of the pixels that occurs at the edge of the swath. In each scene, a smaller area of pixels $(90 \mathrm{~km}$ by $62 \mathrm{~km})$ surrounding each station is included in the study (Fig. 1). The investigation areas mainly contain forests which provide a dark homogeneous background to the clouds.

MODIS Level 2 (Collection 5.1) cloud parameters (Platnick et al., 2003) were analysed in this study. The cloud products include an $\left(r_{\mathrm{e}}\right)$ at $2.1 \mu \mathrm{m}$ and COT that are derived from reflectance measurements at two MODIS wavelength channels and a LWP that is calculated from these (King et al., 2006). The $r_{\mathrm{e}}$ derived from another wavelength channel $(3.7 \mu \mathrm{m})$ rather than the standard at $2.1 \mu \mathrm{m}$ is used in this study, because the $r_{\mathrm{e}}$ at $2.1 \mu \mathrm{m}$ is sometimes overestimated due to reflectance variability on a sub-pixel scale (Zhang et al., 2012). Other cloud parameters used are: cloud top temperature (CTT), cloud phase optical properties, cirrus reflectance and multilayer cloud warning. The three latter parameters are used to sort out pixels that do not contain low-level clouds. Pixels that are classified as containing ice are excluded from the study and pixels with multilayer cloud warnings are also omitted. Furthermore, clouds with too cold a CTT are screened out to ensure that only low-level clouds are studied. The derivation of the temperature limit from ECMWF data is described in Sect. 2.4. Cloud retrievals become uncertain for pixels with a COT < 5 (Zhang et al., 2012) and therefore, pixels with such values are not included in the study. Pixels where $r_{\mathrm{e}}$ at $3.7 \mu \mathrm{m}$ is more than $10 \mu \mathrm{m}$ less than the $r_{\mathrm{e}}$ at $2.1 \mu \mathrm{m}$ were also removed since this indicates an overestimation of the $r_{\mathrm{e}}$ at $2.1 \mu \mathrm{m}$ and uncertainties in the $r_{\mathrm{e}}$ retrievals. At least 50 satellite pixels must pass the above criteria for the scene to be included in the study. Furthermore, scenes where less than $5 \%$ of all cloud pixels are classified as low-level clouds are excluded from the study. All MODIS products used here have a horizontal resolution of $1 \mathrm{~km}$ at nadir, with the exception for the CTT that has a resolution of $5 \mathrm{~km}$ at nadir.

Vavihill and Hyytiälä are located at quite high latitudes which means that the solar zenith angle (SZA) will be high during large parts of the year. A recent study (Grosvenor and Wood, 2014) found that the COT values increase considerably and $r_{\mathrm{e}}$ decrease somewhat with SZA, at SZA higher than $65^{\circ}$. In the current data set, no significant trends of COT or $r_{\mathrm{e}}$ with SZA have been found. The results were also recalculated without the cases with a SZA > 65 and the results regarding how aerosol number concentrations affect $r_{\mathrm{e}}$ and 
COT were barely altered. To investigate whether cloud heterogeneity may have affected the results, the CTT and COT variability was calculated according to the method presented in Grosvenor and Wood (2014). However, none of the heterogeneity parameters were found to be affected by $\mathrm{N}_{130}$ or SZA.

\subsection{Precipitation data}

The BALTEX (the Baltic Sea Experiment) project is a regional hydroclimate project that focuses on the Baltic Sea and the surrounding drainage basin. The project provides composite radar images from $30 \mathrm{C}$-band weather radars covering the entire Baltic region, which includes both Vavihill and Hyytiälä. The images are produced every $15 \mathrm{~min}$ and have a $2 \mathrm{~km}$ horizontal resolution (Michelson, 2006; Michelson and Sunhede, 2004). Because the radar images are generated with such high temporal frequency, the time difference between the satellite overpass and the corresponding radar image is only $5 \mathrm{~min}$.

The areas surrounding the stations seen in Fig. 1 are also analysed in the radar images. The pixels in the satellite and radar images cannot be matched to each other due to the different resolution and positioning systems of the images. However, since not all pixels in the satellite images are included in the study (Sect. 2.2) precipitation that does not originate from the low-level clouds is included in the study if one includes all radar pixels. Therefore, the distance between each radar pixel and the satellite pixel was calculated and only radar pixels within $3.5 \mathrm{~km}$ distance from a low-level cloud pixel are included in the study.

To obtain one precipitation value for each composite radar image the average of only those pixels with a reflectance value greater than $-10 \mathrm{dBZ}$ (no precipitation) were calculated. For images with 4 pixels or less containing values greater than -10 , the precipitation value is set to $-30 \mathrm{dBZ}$.

\subsection{Meteorological data}

Reanalysis data from the ECMWF were used to estimate the meteorological conditions that the clouds form in. The relative humidity (RH) and specific humidity (SH) at $1000 \mathrm{hPa}$ were used to estimate the humidity conditions in the lower atmosphere. Furthermore, the low tropospheric static stability (LTSS), defined as the difference in potential temperature at $700 \mathrm{hPa}$ and the surface (Klein and Hartmann, 1993), was calculated from the ECMWF data. Also, convective available potential energy (CAPE) was used to screen out cases with convective clouds (CAPE $>100 \mathrm{~J} \mathrm{~kg}^{-1}$ ) from the study.

Reanalysis data was also used to calculate the lower temperature limit for the low-level clouds. The maximum cloud top height was set to $1500 \mathrm{~m}$ to select clouds affected by boundary layer aerosol particles, since ground-based measurements of aerosol number concentrations are used. The ECMWF model level closest to $1500 \mathrm{~m}$ was found using the
Table 2. The number of days included in each step of the data analysis for the two stations. The first column shows the number of days with DMPS data, the second column the number of days with DMPS data and simultaneous MODIS satellite scenes, the third column the number of days with low-level clouds manually detected in the satellite scenes and the fourth column the number of days included in the study.

\begin{tabular}{lcccc}
\hline & DMPS & DMPS + MODIS & Low-level & Included Days \\
\hline Vavihill & 2180 & 2129 & 265 & 122 \\
Hyytiälä & 3588 & 2863 & 422 & 261 \\
\hline
\end{tabular}

hydrostatic equation to calculate the height of the levels. To account for inversions, the coldest temperature of all pressure levels up to the one at $1500 \mathrm{~m}$ was used as the limit to sort out low-level clouds in the satellite data.

\subsection{Trajectory analysis}

To estimate the origins of the air masses arriving at the two ground-based stations, back-trajectories were calculated with the Hysplit4 model trajectory (Draxler and Hess, 1997). The meteorological data used in the calculations are from the GDAS (Global Data Assimilation System) and provided by NCEP (National Centers for Environmental Prediction). Back trajectories $(72 \mathrm{~h}$ ) starting at $100 \mathrm{~m}$ above ground level were calculated hourly and an average air mass origin was calculated for the $5 \mathrm{~h}$ of aerosol measurements by calculating a centre of gravity of the 5 trajectories. The azimuth angle between the station and the centre of gravity was then calculated.

\subsection{Aerosol-cloud interaction}

A way to compare results from different types of studies concerning the first indirect aerosol effects was proposed by McComiskey and Feingold (2008). The concept has been named the aerosol-cloud interaction (ACI) and is defined as:

$\mathrm{ACI}=\left.\frac{\partial \ln \mathrm{COT}}{\partial \ln \alpha}\right|_{\mathrm{LWP}}=-\left.\frac{\partial \ln r_{\mathrm{e}}}{\partial \ln \alpha}\right|_{\mathrm{LWP}}=\frac{1}{3} \frac{d \ln N_{\mathrm{d}}}{d \ln \alpha}$,

where $\alpha$ is a proxy for the number of cloud condensation nuclei, $r_{\mathrm{e}}$ is the cloud effective radius and $N_{\mathrm{d}}$ is the cloud droplet number concentration. The first two parts of Eq. (1) requires that the data are divided according to LWP to ensure equality between the different parts of the equation. In this study the ACI is only calculated from the $r_{\mathrm{e}}$ i.e. the second part of Eq. (1). The ACI has been used frequently in previous studies and aircraft in situ measurements generally obtain higher values than remote sensing studies (McComiskey and Feingold, 2008). 
Table 3. Ratios between cloud condensation nuclei measured by $\mathrm{CCN}$ counter for different supersaturation and $\mathrm{N}_{130}$ measured by DMPS.

\begin{tabular}{lrrrrr}
\hline Supersaturation (\%) & 0.1 & 0.2 & 0.4 & 0.7 & 1 \\
\hline Vavihill & 1.24 & 0.75 & 0.54 & 0.42 & 0.36 \\
Hyytiälä & 1.26 & 0.74 & 0.59 & 0.51 & 0.39 \\
\hline
\end{tabular}

\section{Results and discussion}

The number of cases included in the study are 122 for Vavihill and 261 for Hyytiälä. In Table 2, the number of days in each step of the analysis is shown. There are more days with DMPS data available for Hyytiälä than Vavihill, but since Hyytiälä is located further north with less daylight in winter there are fewer satellite data available for this station. Lowlevel clouds seem to be more common over Hyytiälä than Vavihill since a larger percentage of the scenes investigated over Hyytiälä contain low-level clouds. Most cases that were excluded in the automatic screening, although classified as low-level clouds in the manual screening, were omitted because the CTT was too cold.

The $r_{\mathrm{e}}$, COT and LWP values from each satellite scene are generally lognormal distributed and the geometrical average of each scene of these parameters has therefore been calculated. $\mathrm{N}_{130}$ was the aerosol number concentration subset that correlated best with the $r_{\mathrm{e}}$ in this study and was therefore chosen as a proxy for CCN. When convective clouds were studied over the same region (Sporre et al., 2014) $\mathrm{N}_{80}$ (aerosol number concentration of particles with sizes greater than $80 \mathrm{~nm}$ ) was instead found to best correlate with the $r_{\mathrm{e}}$. This finding is expected since low-level clouds have a lower maximum supersaturation than convective clouds. Table 3 shows the average ratios between $\mathrm{N}_{130}$ and the number concentrations measured by the $\mathrm{CCN}$ counter at different supersaturations. At $0.1 \%$ supersaturation the ratios are greater than one implying that $\mathrm{N}_{130}$ is higher than the number of aerosol particles that are activated by the CCN counter. At $0.2 \%$ supersaturation the ratio is lower than one and hence $\mathrm{N}_{130}$ corresponds to a supersaturation somewhere between 0.1 and $0.2 \%$, which is reasonable for low-level clouds.

The seasonal variation in number of cases, $\mathrm{N}_{130}$, CTT, RH at $1000 \mathrm{hPa}$ and the LTSS for the days included in the study is shown in Fig. 2. There are generally more days with lowlevel cloud cover in winter than in summer at both stations. Janssen et al. (2011) studied seasonal variations of low-level clouds over Hyytiälä using satellite data from 9 out of the 10 years used in this study. The focus in that study was however on cloud droplet number concentrations derived from $r_{\mathrm{e}}$ and COT and the areas investigated in the satellite scenes differ somewhat between that and the current study. Janssen et al. (2011) found no seasonal variation in the occurrence of low-level clouds, which does not agree with the results in this study. Since no manual screening of the satellite scenes and higher maximum cloud tops $(2500 \mathrm{~m})$ were used in their study, shallow convective clouds present in summer may have been included in their study. This may be the cause for the differences found regarding seasonal variation in the occurrence of low-level clouds between the two studies.

The meteorological parameters in Fig. $2 \mathrm{f}, \mathrm{h}$ and $\mathrm{j}$, with the exception for LTSS at Vavihill (Fig. 2j), vary considerably with season. None of the meteorological variables on the other hand show a strong variation with air mass origin (Fig. 2e, g and i). Furthermore, Fig. 2d shows that $\mathrm{N}_{130}$ at both stations does not vary with season in this data set, while a previous study utilizing 2 years of DMPS data from both stations, found a seasonal variation in $\mathrm{N}_{100}$ (number of particles above $100 \mathrm{~nm}$ ) at both stations (Asmi et al., 2011). That the seasonal variation is missing in the current study is most likely because the study has less temporal resolution than the Asmi et al. (2011) study. Moreover, $\mathrm{N}_{130}$ is higher at both stations when the air masses arrive from south to southeast (Fig. 2c), where various sources of anthropogenic aerosols are located.

\subsection{Effective radius}

In Table 4 (Vavihill) and Table 5 (Hyytiälä) correlation coefficients between several of the variables investigated in the study are presented. The upper right-hand side of the tables contains the linear correlation coefficients while the lower left-hand side contains the correlation coefficients between the natural logarithm of the parameters. The logarithm has not been applied to the parameters that contain mainly negative values (CTT and dbzc). The $r_{\mathrm{e}}($ at $3.7 \mu \mathrm{m}$ ) is best correlated with LWP and second best with $\mathrm{N}_{130}$ at both stations. The high correlation coefficients with LWP are expected since LWP is calculated from the $r_{\mathrm{e}}$ at $2.1 \mu \mathrm{m}$ (Sect. 2.2) which have similar values to the $r_{\mathrm{e}}$ at $3.7 \mu \mathrm{m}$. The correlation coefficients between the logarithms of the $\mathrm{N}_{130}$ and $r_{\mathrm{e}}$ are higher than the linear correlation coefficients, implying that the relationship between the two parameters is best described by an exponential function. This type of relationship has been widely used in previous studies (Twohy et al., 2005; McComiskey and Feingold, 2008). Furthermore, the $r_{\mathrm{e}}$ is positively correlated with the $\mathrm{RH}$ at $1000 \mathrm{hPa}$, which indicates that the cloud droplet size is affected by the RH in the boundary layer.

Figure $3 \mathrm{a}$ shows the relationship between the logarithms of $r_{\mathrm{e}}$ and $\mathrm{N}_{100}$ obtained in this study, as well as relationships from 2 previous studies of low-level clouds over the ocean. The $\mathrm{N}_{100}$ instead of $\mathrm{N}_{130}$ are used in this figure since this is the $\mathrm{CCN}$ proxy used in the previous studies. Figure $3 \mathrm{a}$ shows that the relationships from Vavihill and Hyytiälä are similar with a slightly steeper slope for Hyytiälä. The large scatter in the figures is expected, since clouds formed in various conditions during different seasons are studied. The relationship found by Sporre et al. (2012) was obtained using 


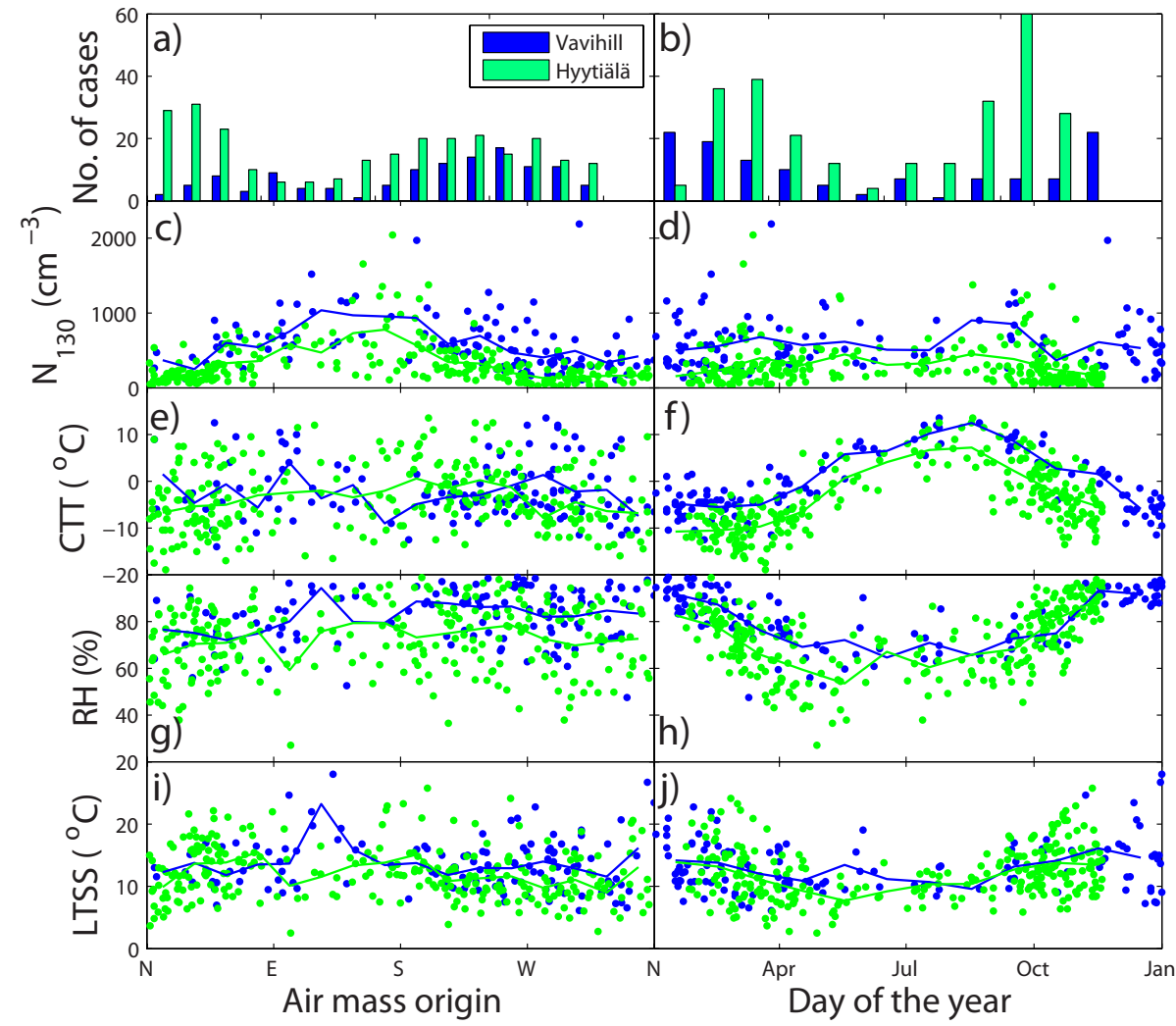

Figure 2. Number of cases, number concentration of aerosol particles with a diameter larger than $130 \mathrm{~nm}\left(\mathrm{~N}_{130}\right)$, cloud top temperature (CTT), relative humidity at $1000 \mathrm{hPa}(\mathrm{RH})$ and low tropospheric static stability (LTSS) plotted against air mass origin (a, c, e, g, i) and day of the year (b, d, f, h, $\mathbf{j}$ ) for Vavihill (blue dots) and Hyytiälä (green dots). The lines in the figures are mean values over $22.5^{\circ}(\mathbf{a}, \mathbf{c}, \mathbf{e}, \mathbf{g}, \mathbf{i})$ and over 30 days $(\mathbf{b}, \mathbf{d}, \mathbf{f}, \mathbf{h}, \mathbf{j})$.

Table 4. Linear correlation coefficients for the data set from Vavihill (top right) and logarithmic correlation coefficients (bottom left). The logarithm has not been applied to the CTT and dbcz parameters since these contain mainly negative values. The stars indicate at what confidence level (* is $95 \%,{ }^{* *}$ is $99 \%$, and ${ }^{* * *}$ is $99.9 \%$ ) the correlation coefficients are significant. $\mathrm{N}_{130}\left(\mathrm{~cm}^{-3}\right)$ is the number of particles with a diameter above $130 \mathrm{~nm}, \mathrm{CTT}\left({ }^{\circ} \mathrm{C}\right)$ is the cloud top temperature, $\mathrm{RH}(\%)$ is the relative humidity, $\mathrm{SH}\left(\mathrm{g} \mathrm{kg}^{-1}\right)$ is the specific humidity, LTSS $\left({ }^{\circ} \mathrm{C}\right)$ is the low tropospheric static stability, dbzc $(\mathrm{dBZ})$ is mean radar reflectivity factor and only cases defined as precipitating are included, $r_{\mathrm{e}}(\mu \mathrm{m})$ is the effective radius, COT is the cloud optical thickness, and LWP $\left(\mathrm{gm}^{-2}\right)$ is the liquid water path.

\begin{tabular}{llllllllll}
\hline & $\mathrm{N}_{130}$ & $\mathrm{CTT}$ & $\mathrm{RH}$ & $\mathrm{SH}$ & LTSS & $\mathrm{dbcz}$ & $r_{\mathrm{e}}$ & COT & LWP \\
\hline $\mathrm{N}_{130}$ & $\mathrm{~N}_{130}$ & 0.12 & -0.05 & 0.15 & 0.02 & -0.18 & $-0.30^{* * *}$ & 0.09 & -0.05 \\
$\mathrm{CTT}$ & $0.18^{*}$ & $\mathrm{CTT}$ & $-0.41^{* * *}$ & $0.91^{* * *}$ & 0.08 & $-0.36^{* *}$ & -0.06 & -0.10 & -0.06 \\
$\mathrm{RH}$ & -0.05 & $-0.40^{* * *}$ & $\mathrm{RH}$ & $-0.35^{* * *}$ & $0.41^{* * *}$ & $0.31^{* *}$ & $0.23^{*}$ & 0.15 & $0.20^{*}$ \\
$\mathrm{SH}$ & 0.17 & $0.90^{* * *}$ & $-0.28^{* *}$ & $\mathrm{SH}$ & -0.13 & $-0.29 * *$ & 0.07 & 0.07 & 0.13 \\
$\mathrm{LTSS}$ & 0.09 & 0.14 & $0.39^{* * *}$ & -0.07 & LTSS & -0.02 & -0.14 & -0.14 & -0.16 \\
$\mathrm{dbcz}$ & $-0.25^{*}$ & & $0.31^{* *}$ & -0.21 & -0.02 & $\mathrm{dbcz}$ & 0.22 & 0.06 & 0.18 \\
$r_{\mathrm{e}}$ & $-0.43^{* * *}$ & -0.03 & $0.21^{*}$ & 0.16 & -0.15 & 0.21 & $r_{\mathrm{e}}$ & $0.26^{* *}$ & $0.61^{* * *}$ \\
$\mathrm{COT}$ & 0.08 & -0.15 & $0.18^{*}$ & 0.08 & -0.16 & 0.10 & $0.32^{* * *}$ & COT & $0.87^{* * *}$ \\
LWP & -0.07 & -0.13 & $0.19^{*}$ & 0.12 & $-0.20^{*}$ & 0.15 & $0.61 * * *$ & $0.92^{* * *}$ & LWP \\
\hline
\end{tabular}

satellite cloud observations over sub-polar oceans combined with ground-based in situ measurements of aerosol number concentrations. Figure $3 \mathrm{a}$ shows that the $r_{\mathrm{e}}$ in their study is generally higher than in the current study, which may be caused by differences in dynamical and/or thermodynamical conditions in the investigation areas. The $r_{\mathrm{e}}$ values obtained from aircraft measurements by Twohy et al. (2005) shown in Fig. 3a, are similar to the current satellite values for low $\mathrm{N}_{100}$ values, but the slope of the relationship is substantially steeper than the ones obtained here. The measurements by 
Table 5. Linear correlation coefficients for the data set from Hyytiälä (top right) and logarithmic correlation coefficients (bottom left). The logarithm has not been applied to the CTT and dbcz parameters since these contain mainly negative values. The stars indicate at what confidence level (* is $95 \%,{ }^{* *}$ is $99 \%$, and ${ }^{* * *}$ is $99.9 \%$ ) the correlation coefficients are significant. The parameters are the same as in Table 4.

\begin{tabular}{llllllllll}
\hline & $\mathrm{N}_{130}$ & $\mathrm{CTT}$ & $\mathrm{RH}$ & $\mathrm{SH}$ & LTSS & $\mathrm{dbcz}$ & $r_{\mathrm{e}}$ & $\mathrm{COT}$ & LWP \\
\hline $\mathrm{N}_{130}$ & $\mathrm{~N}_{130}$ & $0.31^{* * *}$ & -0.10 & $0.30^{* * *}$ & 0.09 & $-0.23^{*}$ & $-0.43^{* * *}$ & 0.01 & $-0.13^{*}$ \\
$\mathrm{CTT}$ & $0.36^{* * *}$ & $\mathrm{CTT}$ & -0.04 & $0.92^{* * *}$ & 0.08 & $-0.26^{* *}$ & -0.08 & 0.02 & 0.00 \\
$\mathrm{RH}$ & -0.10 & -0.05 & $\mathrm{RH}$ & 0.07 & $0.47 * * *$ & 0.13 & $0.18^{* *}$ & $0.26^{* * *}$ & $0.27 * * *$ \\
$\mathrm{SH}$ & $0.24^{* * *}$ & $0.92^{* * *}$ & $0.15^{*}$ & $\mathrm{SH}$ & -0.05 & $-0.22^{*}$ & 0.00 & $0.14^{*}$ & $0.12^{*}$ \\
$\mathrm{LTSS}$ & $0.13^{*}$ & $0.13^{*}$ & $0.54^{* * *}$ & 0.07 & LTSS & -0.03 & -0.03 & 0.08 & 0.05 \\
$\mathrm{dbcz}$ & $-0.23^{*}$ & & 0.15 & -0.17 & -0.03 & $\mathrm{dbcz}$ & 0.05 & 0.12 & 0.06 \\
$r_{\mathrm{e}}$ & $-0.56^{* * *}$ & -0.07 & $0.20^{* *}$ & 0.09 & -0.04 & 0.06 & $r_{\mathrm{e}}$ & $0.24^{* * *}$ & $0.58^{* * *}$ \\
$\mathrm{COT}$ & 0.06 & -0.02 & $0.32^{* * *}$ & $0.15^{*}$ & 0.10 & 0.11 & $0.32^{* * *}$ & $\mathrm{COT}$ & $0.90^{* * *}$ \\
LWP & $-0.15^{*}$ & -0.07 & $0.32^{* * *}$ & 0.12 & 0.04 & 0.08 & $0.65^{* * *}$ & $0.90^{* * *}$ & LWP
\end{tabular}

Twohy et al. (2005) were however performed in a relatively clean marine atmosphere. Dissimilar LWP of the clouds in the different studies could also be a factor explaining why the slopes of the relationships differ.

The variation in $r_{\mathrm{e}}$ with season and air mass origin are shown in Fig. 4a-b. The $r_{\mathrm{e}}$ does not vary much with season, but a small number of relatively high values are present in winter at both stations and also in autumn at Hyytiälä. These high values may have been caused by a combination of high $\mathrm{RH}$ and low $\mathrm{N}_{130}$ values. Janssen et al. (2011) found that the $r_{\mathrm{e}}$ over Hyytiälä have a minimum in spring but no minimum in $r_{\mathrm{e}}$ in spring over Hyytiälä; however no minimum in spring was found in the present study (Fig. 4b). The $r_{\mathrm{e}}$ at Vavihill and Hyytiälä varies with air mass origin and is generally lower when the air masses are arriving from the south (Fig. 4a), which is the sector where the $\mathrm{N}_{130}$ is high (Fig. 2a).

Several previous studies of aerosol indirect effects have divided their cloud data according to the presence of drizzle or only studied clouds that are non-drizzling. When the present data are divided according to precipitation (precipitating cases defined as cases with more than 4 pixels with $\mathrm{dbcz}$ greater than $-10 \mathrm{dbZ}$ ), no significant difference in the results are found compared to when the whole data set is used.

\subsection{Cloud optical thickness}

Very low, non-statistically significant correlations between COT and $\mathrm{N}_{130}$ have been found in this study (Tables 4 and 5). In addition, Fig. $3 \mathrm{~b}$ shows that COT is more or less independent of $\mathrm{N}_{130}$, but the variability in COT seem to increase with $\mathrm{N}_{130}$. The decrease in droplet size associated with an increase in $\mathrm{N}_{130}$ found here hence does not result in an increase in the COT and the COT is positively correlated with $r_{\mathrm{e}}$ at both stations (Tables 4 and 5). The LWP is also well correlated with COT since the LWP is calculated from the COT (Sect. 2.2). The only other parameter that may affect the COT is the RH (at $1000 \mathrm{hPa}$ ) (Tables 4 and 5). Drier conditions in the bound- ary layer seem to be associated with lower COT, but since $\mathrm{RH}$ and $\mathrm{N}_{130}$ are not significantly negatively correlated (see Fig. 5 and Tables 4 and 5), the RH cannot explain the lack of correlation between COT and $\mathrm{N}_{130}$. If $\mathrm{RH}$ at higher altitude in the atmosphere $(850$ or $700 \mathrm{hPa})$ is used instead, the correlation coefficients with COT decrease at both stations (not shown). The RH of the air entrained into the clouds from above does therefore not seem to be controlling the COT. The correlations between $\mathrm{N}_{130}$ and COT do not change significantly when scenes containing drizzle are excluded or when only scenes containing drizzle are investigated.

Twohy et al. (2005) and Costantino and Breon (2013) also found that the COT is unaffected by aerosol number concentrations and aerosol index, respectively. Moreover, these studies found that the missing first indirect effect could be explained by decreased LWP in polluted conditions. The clouds observed in the former study were geometrically thinner while, in the latter study it is hypothesized that the LWP decreases due to enhanced entrainment caused by aerosols. In cloud simulations, small cloud droplets and suppressed precipitation associated with higher $\mathrm{CCN}$ concentrations has also been shown to enhance entrainment into the clouds, leading to a reduction in the LWP (Ackerman et al., 2004). Higher aerosol number concentrations are in the present study associated with both smaller droplets and decreased precipitation rates (Sect. 3.4). There is however, only a weak negative correlation between $\mathrm{N}_{130}$ and LWP (Tables 4 and 5 and Fig. 3c) obtained here for Hyytiälä. Even so, the weak correlation may partly explain why no change in COT with $\mathrm{N}_{130}$ is found in this study.

Figures $4 \mathrm{c}-\mathrm{f}$ show that neither COT nor LWP vary considerably with season or air mass origin. A minimum in COT has previously been found in spring (Janssen et al., 2011), but no seasonal minimum was found in the current data set. The dissimilar results are most likely due to the different data selection used in the two studies (discussed in Sect. 3). 

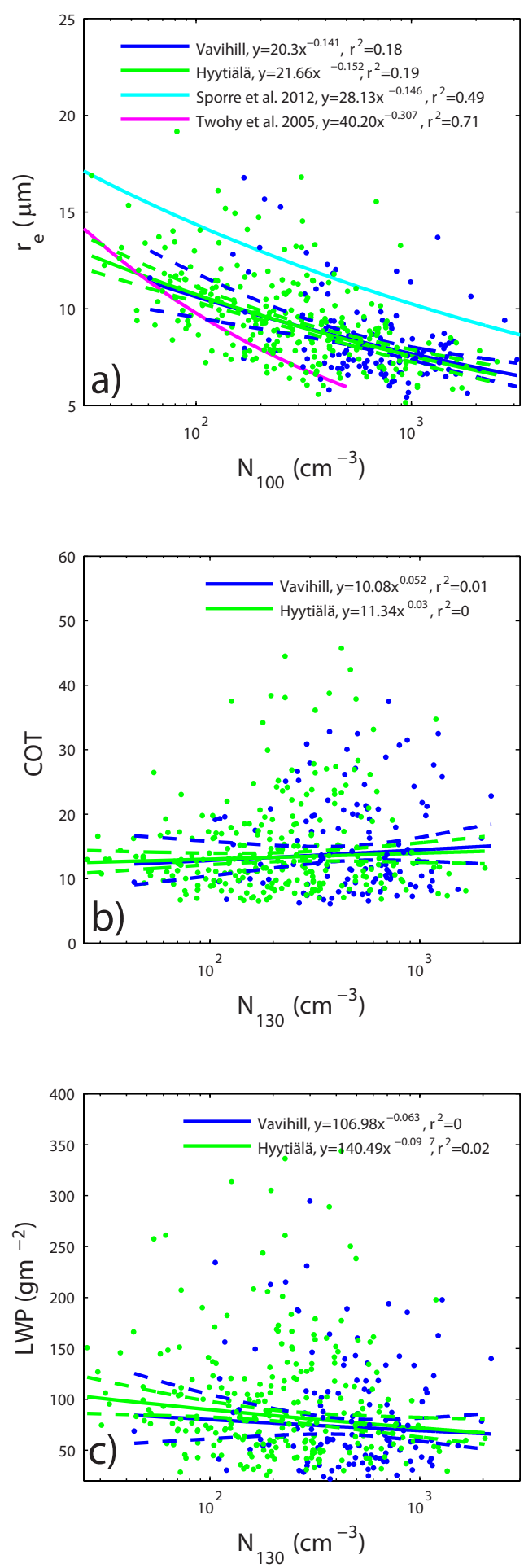

Figure 3. Relationship between (a) $r_{\mathrm{e}}$ and $\mathrm{N}_{100}$, (b) COT and $\mathrm{N}_{130}$ and (c) LWP and $\mathrm{N}_{130}$ for Vavihill (blue lines and dots) and Hyytiälä (green lines and dots). Included in Fig. 3a are also relationships obtained by Sporre et al. (2012) and Twohy et al. (2005).

\subsection{ACI}

The ACI can be calculated from both the $r_{\mathrm{e}}$ and the COT but this requires that the data are divided according to LWP (Eq. 1). The LWP is directly calculated from the $r_{\mathrm{e}}$ at $2.1 \mu \mathrm{m}$ and the COT (Sect. 2.2) and hence is not independent of these parameters. The ACI has therefore only been calculated for the $r_{\mathrm{e}}$ at $3.7 \mu \mathrm{m}$ in this study.

Figures $6 \mathrm{a}-\mathrm{c}$ show how the ACI varies when calculated with different proxies for $\alpha$ (Eq. 1) which in this study is the aerosol number concentration above the diameter $D_{\mathrm{p}}$. Also included in the figure are $\mathrm{ACI} r_{\mathrm{e}}$ data from the study by $\mathrm{Li}$ havainen et al. (2010) in which ground-based measurements of aerosols were compared with satellite data over northern Finland. The data from the current study have been divided into 4 subintervals of LWP, while the data from Lihavainen et al. (2010) includes all values of LWP. The corresponding $r^{2}$ values are shown in Fig. 6d-f while g-i display the uncertainty in the ACI values. The solid markers in the figure denote statistically significant correlations at a $95 \%$ confidence interval. Since there are relatively few cases included from Vavihill not many of the corresponding ACI values are associated with significant correlations. Figure $6 \mathrm{a}-\mathrm{c}$ show that a peak in ACI around a $D_{\mathrm{p}}$ of $130 \mathrm{~nm}$ occurs for most LWP intervals which coincides well with the results from Lihavainen et al. (2010). This means that $r_{\mathrm{e}}$ in this study is most sensitive to the number concentration of particles with a diameter above the diameter $130 \mathrm{~nm}$. For most intervals, the ACI and $r^{2}$ values decline as the lower cut-off diameter for the number concentrations $D_{\mathrm{p}}$ decreases below $100 \mathrm{~nm}$ or increases above $300 \mathrm{~nm}$. Some LWP intervals display a second peak at a $D_{\mathrm{p}}$ of around $25 \mathrm{~nm}$. However, these results should be interpreted with caution, since these LWP intervals contain fewer data points and the uncertainty in the ACI values is higher (Fig. 6g-i).

That the ACI increases significantly with LWP can be seen in Fig. 6, but also in Fig. 7 where the relationship between ACI and LWP is shown. The CCN proxy $\alpha$ is set to $\mathrm{N}_{130}$ here and at least 10 cases are required in each LWP bin for the ACI to be calculated. The same $\alpha$ was used by Lihavainen et al. (2010). Again, most ACI values from Vavihill lack significant correlations due to the low number of cases included. For the Hyytiälä and combined data sets ACI varies from 0.05 for low LWP to 0.25 for high LWP. For the Lihavainen et al. (2010) data no clear dependence of ACI on LWP can be found, but their ACI values also peak at high LWP values. For both studies, the high values of ACI at high LWP should be interpreted with some caution since the number of cases in these LWP bins are smaller than in the other bins. Even without the highest LWP point the ACI seem to increase, if only slightly, with LWP for Hyytiälä or the combined data in the present study. The ACI have previously been found to decrease with LWP in marine stratus clouds (McComiskey et al., 2009), which does not agree with the results here. This may be explained by the different cloud 


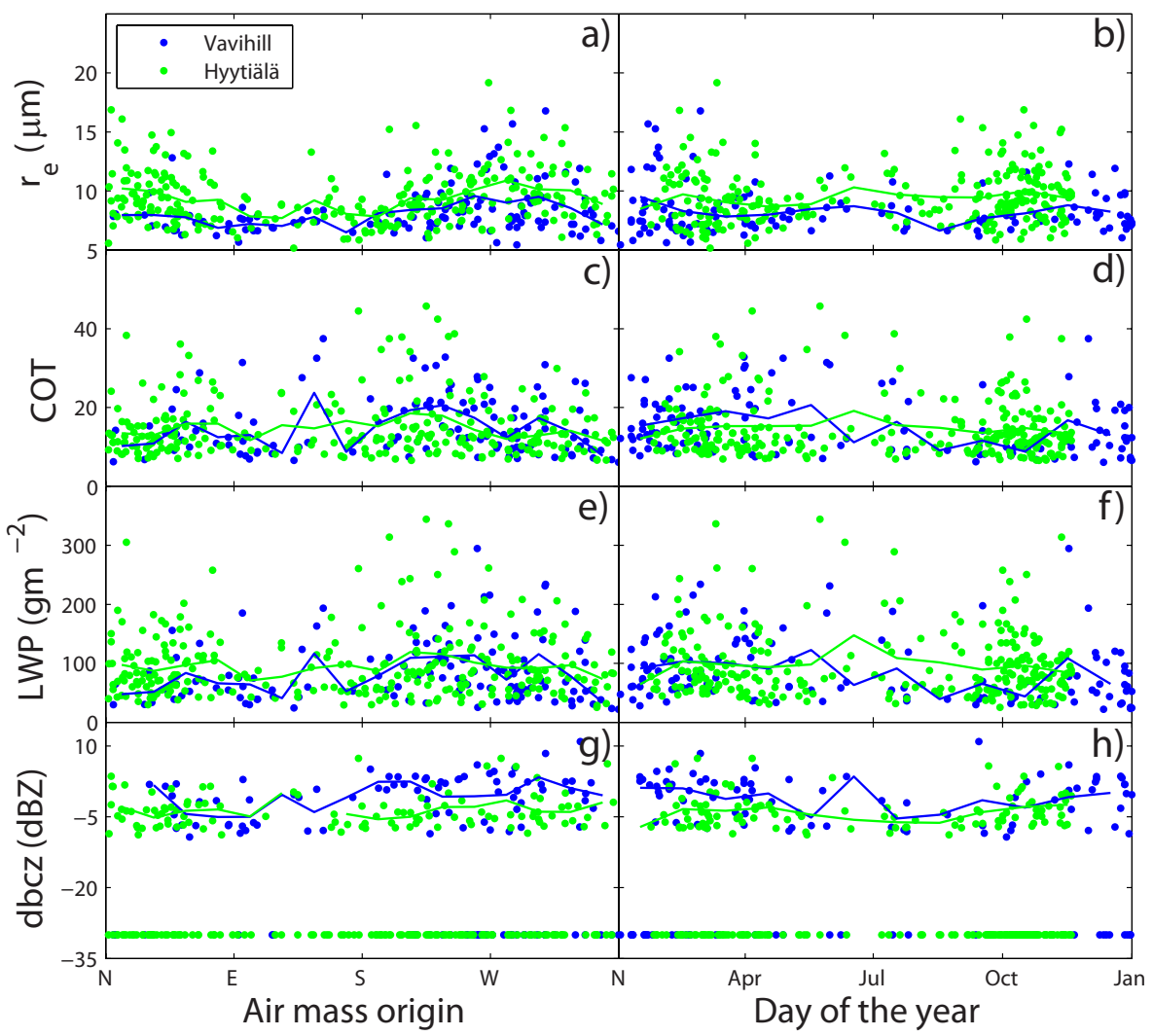

Figure 4. Effective radius $\left(r_{\mathrm{e}}\right)$, cloud optical thickness (COT), liquid water path (LWP) and radar reflectance (dbcz) plotted against air mass origin (a, $\mathbf{c}, \mathbf{e}, \mathbf{g})$ and day of the year $(\mathbf{b}, \mathbf{d}, \mathbf{f}, \mathbf{h})$ for Vavihill (blue dots) and Hyytiälä (green dots). The lines in the figures are mean values over $22.5^{\circ}(\mathbf{a}, \mathbf{c}, \mathbf{e}, \mathbf{g})$ and over 30 days $(\mathbf{b}, \mathbf{d}, \mathbf{f}, \mathbf{h})$.

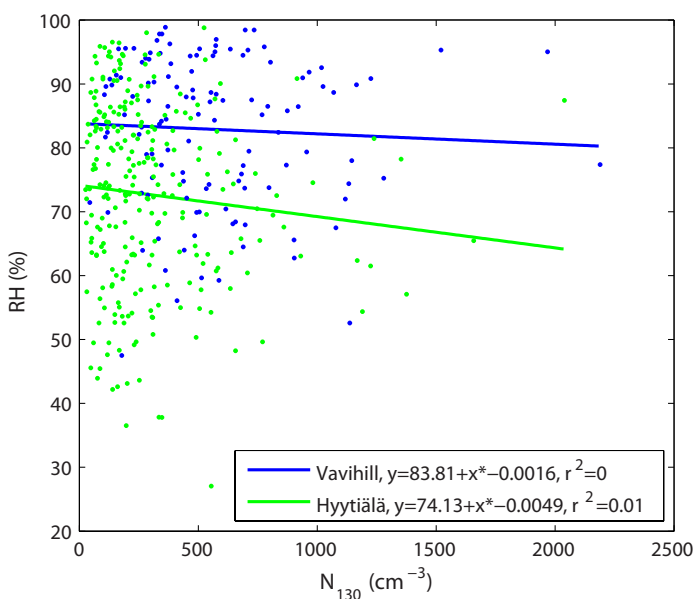

Figure 5. Relationship between relative humidity $(\mathrm{RH})$ and aerosol number concentrations above $130 \mathrm{~nm}\left(\mathrm{~N}_{130}\right)$ for Vavihill (blue) and Hyytiälä (green).

types (marine/continental) investigated and/or, difference in cloud remote sensing (ground-based/satellite). The dissimilar results may also be due to different in situ instruments (nephelometer/DMPS) used and/or that (McComiskey et al.,
2009) have calculated the ACI from COT, while $r_{\mathrm{e}}$ is used in the present study.

\subsection{Precipitation}

In Tables 4 and 5, correlation coefficients obtained between the precipitation parameter and the aerosol, cloud and meteorological parameters investigated in the present study are shown. Only cases associated with precipitation are included in the correlation calculations. The dbcz is significantly correlated to CTT, SH and the logarithm of $\mathrm{N}_{130}$ at both stations. In Fig. $4 \mathrm{~g}-\mathrm{h}$ it can be seen that the dbcz varies neither with season nor with air mass direction.

Relationships between $\mathrm{dbcz}$ and $\mathrm{N}_{130}$ (linear and logarithm of) for only the precipitating cases for the two stations are shown in Fig. 8. The corresponding slopes, correlation coefficients and $p$ values are shown in Table 6. Both subfigures $8 \mathrm{a}$ and $\mathrm{b}$ display negative correlations between $\mathrm{N}_{130}$ and dbcz. Moreover, statistically significant correlations are obtained for Hyytiälä in both Fig. 8a and b but only in the latter for Vavihill.

To determine if the high aerosol number concentrations are suppressing precipitation in the low-level clouds, histograms of $\mathrm{N}_{130}$ were created separately for the precipitat- 


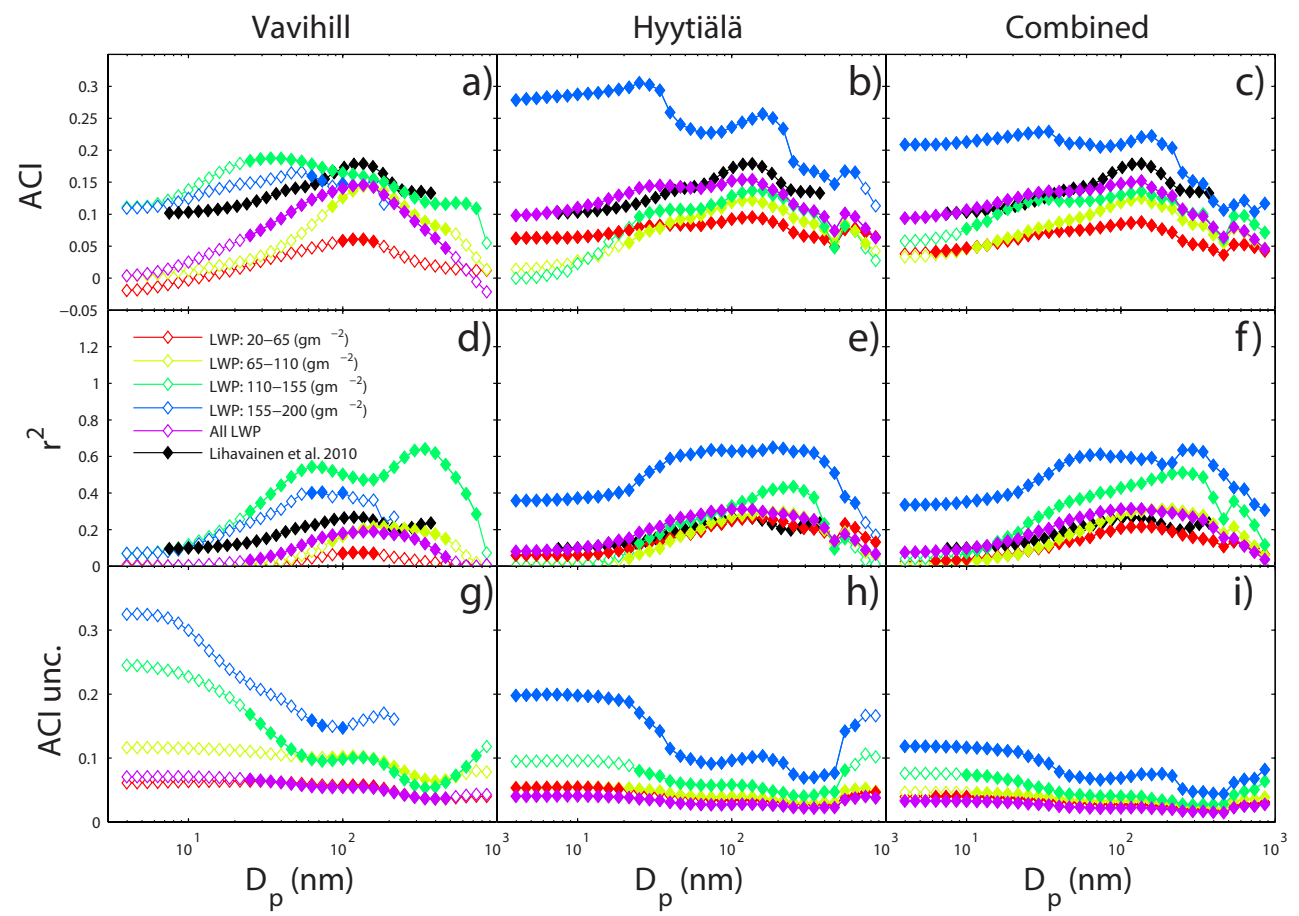

Figure 6. Aerosol-cloud interaction (ACI) versus $D_{\mathrm{p}}$, which is the lower limit for the aerosol number concentration used to calculate the ACI, for (a) Vavihill, (b) Hyytiälä and (c) the combined data set. Squared correlation coefficients $\left(r^{2}\right)$ between the aerosol and cloud parameter as a function of $D_{\mathrm{p}}$ are shown in (d) for Vavihill, (e) for Hyytiälä and (f) for the combined data sets. Uncertainty in the calculated ACI as a function of $D_{\mathrm{p}}$ are displayed in (g) for Vavihill, (h) for Hyytiälä and (i) for the combined data sets. The ACI is calculated from the $r_{\mathrm{e}}$ at $3.7 \mu \mathrm{m}$ and $\mathrm{N}_{130}$. The ACI has been calculated for 4 subsets of the data according to LWP and for all LWP values together. The solid markers denote statistically significant correlations with a $95 \%$ confidence interval. Also included in the figure are results obtained by Lihavainen et al. (2010), who did not divide the data according to liquid water path (LWP).
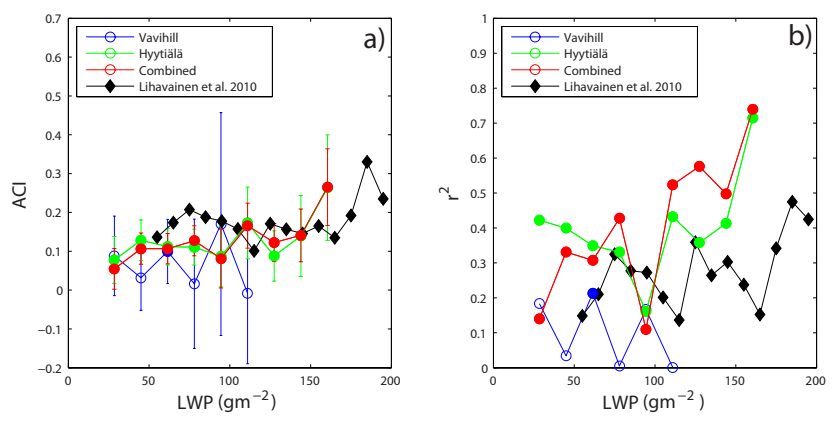

Figure 7. (a) Aerosol-cloud interaction (ACI) as a function of liquid water path (LWP) and (b) the corresponding squared correlation coefficients $\left(r^{2}\right)$ as a function of LWP for Vavihill (blue) and Hyytiälä (green) separately and combined (red). The ACI is calculated with $\alpha$ equal to $\mathrm{N}_{130}$. Results obtained by Lihavainen et al. (2010) (black) are also included in the figure. Filled markers in the figure denote statistically significant correlations at a $95 \%$ confidence interval.

ing cases and the non-precipitating cases (Fig. 9). For Vavihill (Fig. 9a), the distributions are not significantly different from each other and it even appears that cases with no precipitation have lower $\mathrm{N}_{130}$. However, for Hyytiälä (Fig. 9b) the cases with no precipitation have on average higher $\mathrm{N}_{130}$ and the distributions are significantly different from each other with a $95 \%$ confidence interval according to a $t$ test. Since the number of cases at Hyytiälä is greater, the results from this station are thought to be more reliable.

Even though only radar composite pixels adjacent to satellite low-level cloud pixels were included in the study, some precipitating pixels not belonging to the low-level clouds may have been included. Hence, some of the cases determined to be precipitating may not contain any precipitating low-level clouds which would affect the results in Fig. 9. That precipitation pixels not belonging to the lowlevel clouds may be included in the study also introduces uncertainties to the results in Fig. 8. Even so, the large scatter seen in Fig. 8 is expected since clouds formed in different meteorological conditions have been investigated here.

\section{Conclusions}

Ten years of ground-based aerosol measurements have been combined with satellite cloud retrievals and weather radar precipitation data to provide insights on how aerosols affect continental low-level clouds over the Nordic countries. In- 


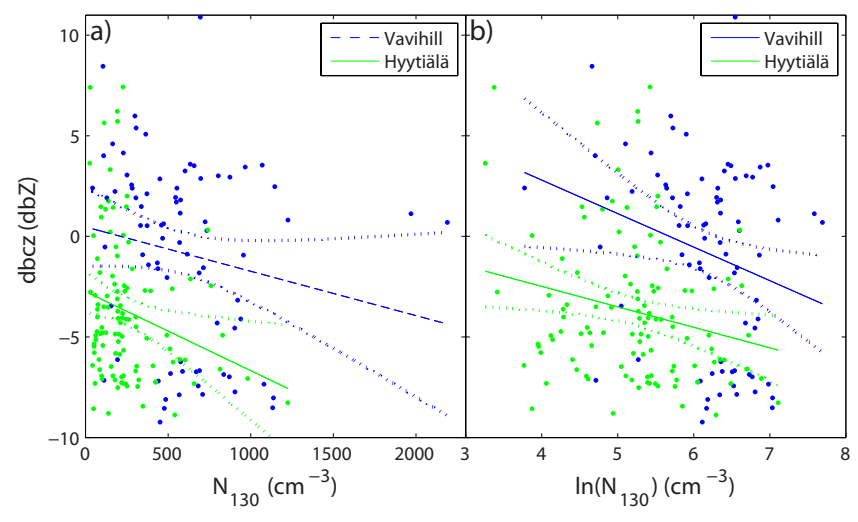

Figure 8. Radar reflectance (dbcz) as a function of aerosol number concentrations above $130 \mathrm{~nm}\left(\mathrm{~N}_{130}\right)$ for only precipitating cases. In (b), the natural logarithm has been applied to the $\mathrm{N}_{130}$. The dotted lines represent the $95 \%$ prediction intervals for the relationship of the combined data set.

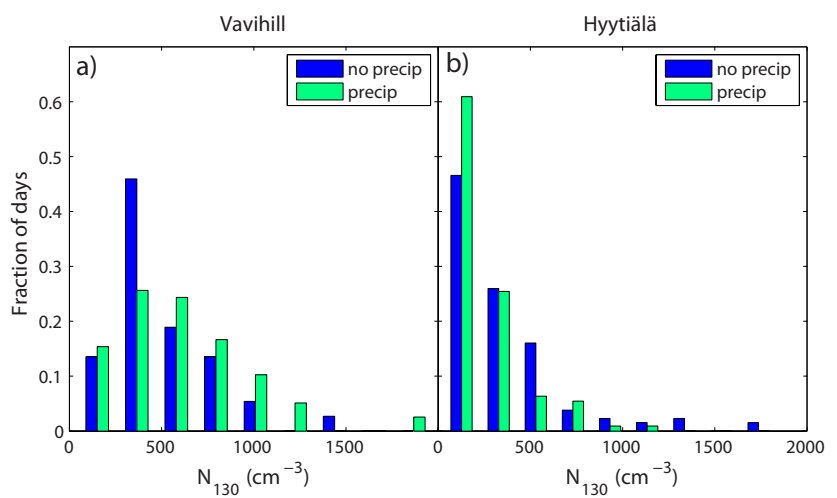

Figure 9. Histograms of aerosol number concentrations for particles larger than $130 \mathrm{~nm}\left(\mathrm{~N}_{130}\right)$, subdivided according to precipitating and non-precipitating cases for (a) Vavihill and (b) Hyytiälä. Precipitating cases are defined as cases with more than 4 pixels with dbcz greater than $-10 \mathrm{dbZ}$.

creasing aerosol number concentration is associated with decreasing $r_{\mathrm{e}}$, but the COT appears to be unaffected by aerosol number concentration. The ACI values (calculated from $r_{\mathrm{e}}$ ) in this study are in the range of $0.10-0.18$ for most LWP bins and highest ACI values are obtained when the total number of particles with a diameter greater than $130 \mathrm{~nm}$ is used as the aerosol proxy. The precipitation rates are found to decrease for higher aerosol number concentrations. In addition, days with precipitation at Hyytiälä are generally associated with lower aerosol number concentrations than those without precipitation. The first indirect aerosol effect can hence not be verified in the present study, but the second indirect effect is noticeable. Similar results were found for convective clouds that were investigated over the same areas in Sweden and Finland (Sporre et al., 2014).
Table 6. Slopes and corresponding $95 \%$ confidence intervals, correlation coefficients and $p$ values of the relationships shown in Fig. 8.

\begin{tabular}{ccccccc}
\hline & $\begin{array}{c}\text { Linear } \\
\text { slope }\end{array}$ & $r$ & $p$ & $\log \left(\mathrm{N}_{130}\right)$ & & \\
& slope & $r$ & $p$ \\
\hline \multirow{2}{*}{ Hyytiälä } & $-2.2 \pm 3$ & -0.18 & 0.12 & $-1.7 \pm 1$ & -0.25 & 0.03 \\
& $-3.9 \pm 3$ & -0.23 & 0.01 & $-1.0 \pm 1$ & -0.23 & 0.02 \\
\hline
\end{tabular}

Acknowledgements. This work was carried out with the support of the FP6 European Commission project European Supersites for Atmospheric Aerosol Research, EUSAAR, contract no. RII3-CT2006-026140; the European Integrated Project on Aerosol, Cloud, Climate and Air Quality Interactions, EUCAARI, contract no. 036833-2; the European Seventh Framework Program, ACTRIS (EU INFRA-2010-1.1.16-262254), Aerosols, Clouds, and Trace gases Research Infra Structure Network; the Strategic Research Program MERGE, Modeling the Regional and Global Earth System; and the Lund Centre for studies of Carbon Cycle and Climate Interaction, LUCCI. We also gratefully acknowledge the support by the Swedish Research Council and from the Nordic Council of Ministers for the Nordic Top-level Research initiative CRAICC: Cryosphere-atmosphere interactions in a changing Arctic climate. This work is further supported by the Academy of Finland Centre of Excellence (grant no. 1118615), and the European Research Council Projects ATMNUCLE (grant no. 227463).

The satellite data from the MODIS instruments were supplied by the US National Aeronautics and Space Agency and the modelled meteorological data were provided by the ECMWF. The weather radar data were supplied by the BALTEX radar data centre. The authors would like to thank Daniel Michelson for his help with the manuscript.

Edited by: S. M. Noe

\section{References}

Aalto, P., Hämeri, K., Becker, E., Weber, R., Salm, J., Mäkelä, J., Hoell, C., O'Dowd, C., Karlsson, H., and Hansson, H.: Physical characterization of aerosol particles during nucleation events, Tellus B, 53, 344-358, 2001.

Ackerman, A. S., Kirkpatrick, M. P., Stevens, D. E., and Toon, O. B.: The impact of humidity above stratiform clouds on indirect aerosol climate forcing, Nature, 432, 1014-1017, 2004.

Albrecht, B. A.: Aerosols, Cloud Microphysics, and Fractional Cloudiness, Science, 245, 1227-1230, 1989.

Asmi, A., Wiedensohler, A., Laj, P., Fjaeraa, A.-M., Sellegri, K., Birmili, W., Weingartner, E., Baltensperger, U., Zdimal, V., Zikova, N., Putaud, J.-P., Marinoni, A., Tunved, P., Hansson, H.C., Fiebig, M., Kivekäs, N., Lihavainen, H., Asmi, E., Ulevicius, V., Aalto, P. P., Swietlicki, E., Kristensson, A., Mihalopoulos, N., Kalivitis, N., Kalapov, I., Kiss, G., de Leeuw, G., Henzing, B., Harrison, R. M., Beddows, D., O’Dowd, C., Jennings, S. G., Flentje, H., Weinhold, K., Meinhardt, F., Ries, L., and Kulmala, M.: Number size distributions and seasonality of submicron particles in Europe 2008-2009, Atmos. Chem. Phys., 11, 5505-5538, doi:10.5194/acp-11-5505-2011, 2011. 
Boucher, O., Randall, D., Artaxo, P., Bretherton, C., Feingold, G., Forster, P., Kerminen, V.-M., Kondo, Y., Liao, H., Lohmann, U., Rasch, P., Satheesh, S. K., Sherwood, S., Stevens, B., and Zhang, X. Y.: Clouds and Aerosols, in: Climate Change 2013: The Physical Science Basis. Contribution of Working Group I to the Fifth Assessment Report of the Intergovernmental Panel on Climate Change edited by: Stocker, T. F., Qin, D., Plattner, G.-K., Tignor, M., Allen, S. K., Boschung, J., Nauels, A., Xia, Y., Bex, V., and Midgley, P. M., Cambridge University Presss, Cambridge, United Kingdom and New York, NY, USA., 2013.

Brenguier, J. L., Pawlowska, H., and Schuller, L.: Cloud microphysical and radiative properties for parameterization and satellite monitoring of the indirect effect of aerosol on climate, J. Geophys Res.-Atmos, 108, 8632, doi:10.1029/2002jd002682, 2003.

Bretherton, C. S., Blossey, P. N., and Uchida, J.: Cloud droplet sedimentation, entrainment efficiency, and subtropical stratocumulus albedo, Geophys Res Lett, 34, L03813, doi:10.1029/2006g1027648, 2007.

Chameides, W. L., Luo, C., Saylor, R., Streets, D., Huang, Y., Bergin, M., and Giorgi, F.: Correlation between modelcalculated anthropogenic aerosols and satellite-derived cloud optical depths: Indication of indirect effect?, J. Geophys Res.Atmos, 107, 4085, doi:10.1029/2000jd000208, 2002.

Cheng, C. T., Wang, W. C., and Chen, J. P.: A modelling study of aerosol impacts on cloud microphysics and radiative properties, Q. J. Roy. Meteor. Soc., 133, 283-297, 2007.

Costantino, L. and Bréon, F.-M.: Aerosol indirect effect on warm clouds over South-East Atlantic, from co-located MODIS and CALIPSO observations, Atmos. Chem. Phys., 13, 69-88, doi:10.5194/acp-13-69-2013, 2013.

Draxler, R. and Hess, G.: Description of the HYSPLIT_4 Modeling System, NOAA Technical Memorandum ERL ARL-224, 24, 1997.

Ferek, R. J., Garrett, T., Hobbs, P. V., Strader, S., Johnson, D., Taylor, J. P., Nielsen, K., Ackerman, A. S., Kogan, Y., Liu, Q. F., Albrecht, B. A., and Babb, D.: Drizzle suppression in ship tracks, J. Atmos. Sci., 57, 2707-2728, 2000.

Fors, E. O., Swietlicki, E., Svenningsson, B., Kristensson, A., Frank, G. P., and Sporre, M.: Hygroscopic properties of the ambient aerosol in southern Sweden - a two year study, Atmos. Chem. Phys., 11, 8343-8361, doi:10.5194/acp-11-8343-2011, 2011.

Grosvenor, D. P. and Wood, R.: The effect of solar zenith angle on MODIS cloud optical and microphysical retrievals within marine liquid water clouds, Atmos. Chem. Phys., 14, 7291-7321, doi:10.5194/acp-14-7291-2014, 2014.

Guo, H., Penner, J. E., Herzog, M., and Pawlowska, H.: Examination of the aerosol indirect effect under contrasting environments during the ACE-2 experiment, Atmos. Chem. Phys., 7, 535-548, doi:10.5194/acp-7-535-2007, 2007.

Hari, P. and Kulmala, M.: Station for Measuring EcosystemAtmosphere Relations (SMEAR II), Boreal Environ. Res., 10, 315-322, 2005.

Janssen, R. H. H., Ganzeveld, L. N., Kabat, P., Kulmala, M., Nieminen, T., and Roebeling, R. A.: Estimating seasonal variations in cloud droplet number concentration over the boreal forest from satellite observations, Atmos. Chem. Phys., 11, 7701-7713, doi:10.5194/acp-11-7701-2011, 2011.

King, M., Platnick, S., Hubanks, P., Arnold, G., Moody, E., Wind, G., and Wind, B.: Collection 005 Change Summary for the MODIS Cloud Optical Property (06_OD) Algorithm, available at: modis-atmos.gsfc.nasa.gov/C005_Changes/C005_ CloudOpticalProperties_ver311.pdf (last access: 30 January 2009), 2006.

Klein, S. A. and Hartmann, D. L.: The seasonal cycle of low stratiform clouds, J. Climate, 6, 1587-1606, 1993.

Kristensson, A., Dal Maso, M., Swietlicki, E., Hussein, T., Zhou, J., Kerminen, V.-M., and Kulmala, M.: Characterization of new particle formation events at a background site in Southern Sweden: relation to air mass history, Tellus B, 60, 330-344, doi:10.1111/j.1600-0889.2008.00345.x, 2008.

Lihavainen, H., Kerminen, V.-M., and Remer, L. A.: Aerosol-cloud interaction determined by both in situ and satellite data over a northern high-latitude site, Atmos. Chem. Phys., 10, 1098710995, doi:10.5194/acp-10-10987-2010, 2010.

Lohmann, U., Rotstayn, L., Storelvmo, T., Jones, A., Menon, S., Quaas, J., Ekman, A. M. L., Koch, D., and Ruedy, R.: Total aerosol effect: radiative forcing or radiative flux perturbation?, Atmos. Chem. Phys., 10, 3235-3246, doi:10.5194/acp-10-32352010, 2010.

Lu, M.-L., Sorooshian, A., Jonsson, H. H., Feingold, G., Flagan, R. C., and Seinfeld, J. H.: Marine stratocumulus aerosol-cloud relationships in the MASE-II experiment: Precipitation susceptibility in eastern Pacific marine stratocumulus, J. Geophys. Res.Atmos., 114, D24203, doi:10.1029/2009jd012774, 2009.

McComiskey, A. and Feingold, G.: Quantifying error in the radiative forcing of the first aerosol indirect effect, Geophys. Res. Lett., 35, L02810, doi:10.1029/2007g1032667, 2008.

McComiskey, A., Feingold, G., Frisch, A. S., Turner, D. D., Miller, M. A., Chiu, J. C., Min, Q. L., and Ogren, J. A.: An assessment of aerosol-cloud interactions in marine stratus clouds based on surface remote sensing, J. Geophys Res.-Atmos, 114, D09203, doi:10.1029/2008JD011006, 2009.

Menon, S., Del Genio, A. D., Kaufman, Y., Bennartz, R., Koch, D., Loeb, N., and Orlikowski, D.: Analyzing signatures of aerosolcloud interactions from satellite retrievals and the GISS GCM to constrain the aerosol indirect effect, J. Geophys. Res.-Atmos., 113, D14S22, 10.1029/2007jd009442, 2008.

Michelson, D.: The Swedish weather radar production chain, Proc. ERAD 2006, 2006.

Michelson, D. B., and Sunhede, D.: Spurious weather radar echo identification and removal using multisource temperature information, Meteorol. Appl., 11, 1-14, 2004.

Platnick, S., King, M. D., Ackerman, S. A., Menzel, W. P., Baum, B. A., Riedi, J. C., and Frey, R. A.: The MODIS cloud products: algorithms and examples from Terra, IEEE T. Geosci. Remote, 41, 459-473, doi:10.1109/Tgrs.2002.808301, 2003.

Sihto, S.-L., Mikkilä, J., Vanhanen, J., Ehn, M., Liao, L., Lehtipalo, K., Aalto, P. P., Duplissy, J., Petäjä, T., Kerminen, V.M., Boy, M., and Kulmala, M.: Seasonal variation of CCN concentrations and aerosol activation properties in boreal forest, Atmos. Chem. Phys., 11, 13269-13285, doi:10.5194/acp-1113269-2011, 2011.

Sporre, M. K., Glantz, P., Tunved, P., Swietlicki, E., Kulmala, M., and Lihavainen, H.: A study of the indirect aerosol effect on subarctic marine liquid low-level clouds using MODIS cloud data and ground-based aerosol measurements, Atmos. Res., 116, 5666, 2012. 
Sporre, M. K., Swietlicki, E., Glantz, P., and Kulmala, M.: A longterm satellite study of aerosol effects on convective clouds in Nordic background air, Atmos. Chem. Phys., 14, 2203-2217, doi:10.5194/acp-14-2203-2014, 2014.

Stevens, B., and Feingold, G.: Untangling aerosol effects on clouds and precipitation in a buffered system, Nature, 461, 607-613, 2009.

Twohy, C. H., Petters, M. D., Snider, J. R., Stevens, B., Tahnk, W., Wetzel, M., Russell, L., and Burnet, F.: Evaluation of the aerosol indirect effect in marine stratocumulus clouds: Droplet number, size, liquid water path, and radiative impact, J. Geophys Res.Atmos, 110, D08203, doi:10.1029/2004jd005116, 2005.
Twomey, S.: Pollution and Planetary Albedo, Atmos. Environ., 8, 1251-1256, 1974.

Wood, R.: Cancellation of aerosol indirect effects in marine stratocumulus through cloud thinning, J. Atmos. Sci., 64, 2657 2669, 2007.

Zhang, Z., Ackerman, A. S., Feingold, G., Platnick, S., Pincus, R., and Xue, H.: Effects of cloud horizontal inhomogeneity and drizzle on remote sensing of cloud droplet effective radius: Case studies based on large-eddy simulations, J. Geophys. Res.Atmos., 117, D19208, doi:10.1029/2012jd017655, 2012. 